\title{
A Factor Involved in \\ Chloramphenicol Resistance in Streptomyces coelicolor A3(2): Its Transfer in the Absence of the Fertility Factor
}

\author{
By G. SERMONTI, ANNA PETRIS, MARIARITA MICHELI AND \\ LUISA LANFALONI \\ Institute of Histology and Embryology, The University, Via Elce di Sotto, \\ Perugia, Italy
}

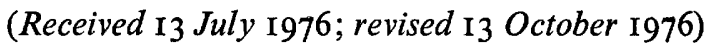

\begin{abstract}
SUMMARY
An element controlling chloramphenicol resistance $(\mathrm{chl})$ was detected in Streptomyces coelicolor A3(2). Strains sensitive to I $\mu \mathrm{g}$ chloramphenicol ml-1 were obtained among dark scarlet variants. Transfer of the resistance factor was attempted in matings between chloramphenicol-resistant $\left(\mathrm{Chl}^{+}\right)$and chloramphenicol-sensitive $\left(\mathrm{Chl}^{-}\right)$strains, both of which lacked the SCPI fertility factor. Transfer of $c h l$ was obtained at a much higher rate than that expected for chromosomal markers in $\mathrm{SCPI}^{-} \times \mathrm{SCPI}^{-}$matings. However, in these particular crosses the latter was also several times higher than usual. All recombinants for chromosomal markers were $\mathrm{Chl}^{+}$. Attempts to locate the $\mathrm{chl}$ element failed to distinguish between a chromosomal and an extrachromosomal site. The observed increase in the recombination frequency for chromosomal markers suggests that the $c h l$ element may promote recombination.
\end{abstract}

\section{INTRODUCTION}

Although a large number of plasmid-like elements have been reported in the genus Streptomyces (Kirby, Wright \& Hopwood, 1975; Sermonti, 1975a), a general criterion for their detection and definition is still lacking. If a plasmid is operationally defined as a non-essential element from which the cell may be freed by curing agents and with which it can be reinfected only by contact with another plasmid-bearing cell, then no single case satisfying this definition has been reported in Streptomyces, with the possible exception of a plasmid controlling tyrosinase in S. scabies (Gregory \& Shyu, I96I). The well-known SCPI element (Vivian, 197I) is cured with low efficiency and only after extensive studies was its plasmid nature substantiated (Hopwood et al., I973). The SCPI plasmid is found in five different states in various strains of $S$. coelicolor A3(2). It may be absent ( $\mathrm{SCPI}^{-}$strains, formerly designated UF), present in the free state ( $\mathrm{SCPI}^{+}$strains, formerly designated $\mathrm{IF}$ ), present in the free state and bearing a chromosome segment $\left(\mathrm{SCPr}^{\prime}\right)$, stably associated with the chromosome and promoting its bidirectional transfer (NF strains), or unstably associated with the chromosome and promoting unidirectional transfer (new donors) (Hopwood et al., 1973). In approaching the study of unstable genetic elements in Streptomyces it appears initially more advisable to collect different lines of evidence from experiments with various strains, rather than trying to follow a preconceived simplified model which might be misleading. In this paper we document the peculiar role in some $\mathrm{SCPI}^{-}$strains of $S$. coelicolor A3(2) of an element controlling chloramphenicol resistance, the occurrence of which was preliminarily reported by one of us (Sermonti, 1975b). 
Table I. Characteristics of the chloramphenicol-resistant $\left(\mathrm{Chl}^{+}\right)$strains and their sensitive $\left(\mathrm{Chl}^{-}\right)$derivatives

\begin{tabular}{|c|c|c|c|c|}
\hline Strain & Fertility type & $\begin{array}{l}\text { Response to } \\
\text { chloramphenicol* }\end{array}$ & Chromosomal markers & $\begin{array}{c}\text { Strain from } \\
\text { which derived }\end{array}$ \\
\hline 39 & NF & $\mathrm{chl}^{+}$ & hisAI & - \\
\hline 505 & NF & $\operatorname{chl} \mathbf{I}^{-}$ & hisAI & 39 \\
\hline 316 & $\mathrm{SCPI}^{-}$ & $\operatorname{chl}^{+}$ & his $D_{3}$ pheAI strAI & - \\
\hline 312 & $\mathrm{SCPI}^{-}$ & $\mathrm{chl}^{+}$ & $\arg A I$ uraAI strAI & - \\
\hline 506 & SCPI $^{-}$ & $\operatorname{chl}-2^{-}$ & $\arg A I$ uraAI strAI & 312 \\
\hline 509 & $\mathrm{SCPI}^{-}$ & chl-5 & $\arg A I$ uraAI strAI & 312 \\
\hline 510 & $\mathrm{SCPI}^{-}$ & chl-6- & $\arg A I$ uraAI strAI & 312 \\
\hline 219 & $\mathrm{SCPI}^{-}$ & $\mathrm{chl}^{+}$ & metA2 pheAI strAI & - \\
\hline 511 & $\mathrm{SCP}_{1}^{-}$ & $\operatorname{chl-7^{-}}$ & metA2 pheAI strAI & 219 \\
\hline 512 & $\mathrm{SCP}_{I^{-}}$ & chl-8- & metA2 pheAI strAI & 219 \\
\hline
\end{tabular}
chloramphenicol $\mathrm{ml}^{-1}$.

\section{METHODS}

Organisms and media. All strains used trace back to Streptomyces coelicolor A3(2) (Hopwood \& Sermonti, I962). The three naturally chloramphenicol-resistant $\left(\mathrm{Chl}^{+}\right)$strains, 39, 312 and 316, were described previously (Puglia et al., 1973) and their characteristics are reported in Table $\mathrm{I}$. The culture media, crossing procedures and methods for strain characterization were as described by Hopwood \& Sermonti (1962). RM2 was used as complete medium (Hopwood \& Sermonti, I962).

Detection of chloramphenicol-sensitive variants. Chloramphenicol-sensitive variants $\left(\mathrm{Chl}^{-}\right)$ were detected among rare colonies or sectors showing a dark scarlet colour, poor sporulation and lacking, even at alkaline $\mathrm{pH}$, the blue pigment characteristic of the species. The chloramphenicol sensitivity of some scarlet variants was discovered by chance (Sermonti, $1975 b$ ). Subsequently scarlet variants were systematically scored for chloramphenicol sensitivity and about half were found to be sensitive. Isolation of pure $\mathrm{Chl}^{-}$clones often required two or three reclonings of variant colonies. $\mathrm{Chl}^{-}$strains isolated from three $\mathrm{Chl}^{+}$strains are listed in Table $\mathrm{I}$.

Determination of resistance level. The assumed $\mathrm{Chl}^{-}$strains were streaked, together with the $\mathrm{Chl}^{+}$strains from which they derived, on the surface of $\mathrm{RM} 2$ agar containing various concentrations of chloramphenicol. A concentration of $\mathrm{I} \cdot 25 \mu \mathrm{g}$ chloramphenicol ml ${ }^{-1}$ was used as diagnostic of the $\mathrm{Chl}^{+} / \mathrm{Chl}^{-}$trait throughout this work.

Curing conditions. All attempts at curing were performed by streaking a $\mathrm{Chl}^{+}$strain on RM2 agar containing the assumed curing agent. The strain was grown to sporulation and then the spores were plated on medium without the curing agent to screen for scarlet colonies or sectors. Acridine orange was used at a final concentration of Io or $30 \mu \mathrm{g} \mathrm{ml}^{-1}$ and ethidium bromide at $5 \mu \mathrm{g} \mathrm{ml}^{-1}$. Ultraviolet light was also used, either by irradiation of plated spores followed by incubation and screening of the colonies which developed from the surviving spores, or by irradiation of streaks of spores which were then grown to sporulation when the spores were plated and the resulting colonies screened. The latter procedure was also applied to streaks of spores on media supplemented with acridine orange or ethidium bromide at the concentrations given above. 
RESULTS

\section{Isolation of chloramphenicol-sensitive variants}

Chloramphenicol-sensitive variants were not detected by direct testing, either with or without treatment with assumed curing agents. However, they were detected among an extreme type of morphological variant, characterized by a colour ranging from dark scarlet to purple and by very poor sporulation. This variant was repeatedly isolated both from the same strain and from several different strains (Table I), although not from all strains tested (e.g. never from strain 3I6). It appeared at a frequency of about 0.5 to $2 \%$. When tested against several antibiotics, about half the scarlet variants were sensitive to $\mathrm{r} \mu \mathrm{g}$ chloramphenicol $\mathrm{ml}^{-1}$, while the parent strains grew on media containing up to $5 \mu \mathrm{g}$ chloramphenicol ml-1. Strain $505\left(c h l-I^{-}\right)$was isolated initially because of its minute size. When its spores were plated, a striking multitude of morphological types, varying in sporulation, colony colour, texture and size, were formed. A breakdown of the genetic balance was apparent. Scarlet colonies were isolated from this heterogeneous population and recloned. The frequency of the variant phenotype increased with repeated re-isolation, and the population consisted entirely of scarlet colonies after the third re-isolation. Strain $506\left(\mathrm{chl}-2^{-}\right)$was isolated as a single scarlet colony and strain $5 \mathrm{II}\left(\mathrm{chl}-7^{-}\right)$as a scarlet sector from an old slant (Table I). All the variant strains tested were characterized by marked instability, gradually reverting to the wild type $\mathrm{Chl}^{+}$. They required repeated recloning to be first isolated in a homogeneous state, and subsequent purification from time to time to prevent spontaneous reversion. Some isolates (e.g. strain 5I I $\mathrm{chl}_{-7}{ }^{-}$) were particularly unstable. Storage of spores and ground hyphae in $20 \%(\mathrm{v} / \mathrm{v})$ glycerol at $-20{ }^{\circ} \mathrm{C}$ gave sufficient stability for culture maintenance (Hopwood et al., 1973).

Attempts to increase the rate of appearance of the scarlet variant by treatment with ultraviolet light, acridine orange and ethidium bromide, whether alone or in combination, gave inconsistent results. The recurrent, frequent and independent appearance of the same phenotype suggested that the variation was determined by an extrachromosomal factor. This factor appears to be independent of the SCPI plasmid because: (i) $\mathrm{Ch}^{-}$variants were obtained both from NF and UF (SCPI ${ }^{-}$) strains (Table I); (ii) a $\mathrm{Chl}^{-}$variant from an NF strain retained high frequency polarized fertility thus indicating that the $\mathrm{Chl}^{-}$trait was not due to loss of the SCPI plasmid (Sermonti, $1975 b$ ); and (iii) stock $\mathrm{SCPI}^{-}$strains were frequently resistant to chloramphenicol.

\section{Search for infectious transfer of the chl factor}

Previous attempts to 'infect' $\mathrm{Chl}^{-}$strains with the $\mathrm{chl}$ factor by contact with $\mathrm{Ch}^{+}$strains gave no evidence of massive transfer of the factor (Sermonti, 1975 b). To investigate transfer of $\mathrm{Chl}^{+}$in the presence of very low chromosomal marker transfer, mixed cultures of pairs of $\mathrm{UF}\left(\mathrm{SCP}_{\mathrm{I}}{ }^{-}\right)$strains were prepared. After I week the spores formed were plated on media which supported growth of the parents, on a medium selecting possible convertants (containing the nutritional requirements of the sensitive parent plus chloramphenicol), and on four selective media, to evaluate the recombination rate of the standard markers.

The rate of transfer of $\mathrm{Chl}^{+}$in various parallel crosses was very variable, sometimes exceeding and sometimes less than that of the standard markers. The most striking effect was the very high rate of recombination of the chromosomal markers, which, when expressed relative to the frequency of the minority sensitive parent, was increased from $600-$ to $30000-$ fold over that observed in the control cross $\left(\mathrm{Chl}^{+} \times \mathrm{Chl}^{+}\right)$(Table 2). A lower increase, if any, was observed relative to the frequency of the other parent. The $\mathrm{Chl}^{+}$trait was therefore 


\section{Table 2. Transfer of the $\mathrm{Chl}^{+}$trait and recombinant frequency in $\mathrm{SCP}_{1}-\times \mathrm{SCP}^{-}$matings}

Crosses: strain $316 \mathrm{SCPI}^{-}$his $\mathrm{D}_{3}$ pheAI strAI chl+ $\times$ strain $3 \mathrm{I}_{2} \mathrm{SCPI}^{-} \operatorname{argAI}$ uraAI strAI chl ${ }^{+}$and strain $316 \mathrm{SCPI}^{-}$his $D_{3}$ pheAI str $A$ I chl $^{+} \times$strain $506 \mathrm{SCPI}^{-}$arg $A$ I uraAI strAI chl-2-- Transferants were scored following selection on minimal medium (MM) supplemented with arginine, uracil and chloramphenicol, and recombinants on MM supplemented with histidine and uracil.

\begin{tabular}{|c|c|c|c|c|c|c|c|}
\hline \multirow[b]{3}{*}{ Cross } & \multirow{3}{*}{$\begin{array}{c}\text { Expt } \\
\text { no. }\end{array}$} & \multicolumn{6}{|c|}{ Colonies per unit volume } \\
\hline & & \multicolumn{2}{|c|}{ Parental } & \multicolumn{2}{|c|}{ Transferants } & \multicolumn{2}{|c|}{ Recombinants } \\
\hline & & 316 & $312 / 506$ & No. & $\% *$ & No. & $\% *$ \\
\hline $\begin{array}{l}3 \mathrm{I} 6 \times 3 \mathrm{I}^{2} \\
\left(\mathrm{Chl}^{+} \times \mathrm{Chl}^{+}\right)\end{array}$ & $P_{33}$ & $20.0 \times 10^{5}$ & $10 \times 10^{5}$ & - & - & $14 \cdot 7$ & 0.0015 \\
\hline \multirow{3}{*}{$\begin{array}{l}3 \mathrm{I} 6 \times 506 \\
\left(\mathrm{Chl}^{+} \times \mathrm{Chl}^{-}\right)\end{array}$} & $\mathrm{P}_{3} \mathrm{I}$ & $4.1 \times 10^{5}$ & 2760 & $94 \cdot 0$ & $3 \cdot 5$ & $28 \cdot 4$ & $1 \cdot I$ \\
\hline & P32 & $8.8 \times 10^{5}$ & 540 & $4 \cdot 3$ & 0.8 & $11 \cdot 0$ & $2 \cdot 0$ \\
\hline & $P_{34}$ & $\mathrm{I} \cdot 0 \times 10^{5}$ & $\begin{array}{l}208 \\
\text { I I9t }\end{array}$ & $\begin{array}{r}150^{\circ} \\
\text { II } 5.0\end{array}$ & $\begin{array}{r}7 \cdot 2 \\
96 \cdot 0\end{array}$ & $\begin{array}{l}116.0 \\
102 \cdot 0\end{array}$ & $\begin{array}{l}55 \cdot 7 \\
85 \cdot 7\end{array}$ \\
\hline
\end{tabular}

* Referred to the minority parent (3I2 or 506).

$\uparrow$ The data in this line were obtained after complete analysis of colonies grown on a semi-selective medium that did not contain chloramphenicol (Table 3 ).

Table 3. Genotypes of colonies recovered on semi-selective medium from the mating

$$
\mathrm{SCP}_{1}-\mathrm{Chl}^{+} \times \mathrm{SCP}_{I^{-}} \mathrm{Chl}^{-}
$$

Cross $\mathrm{P}_{34}$ : strain $316 \mathrm{SCPI}^{-}$hisD3 pheAI (strAI) chl $^{+} \times$strain $506 \mathrm{SCPI}^{-} \arg A I$ uraAI (strAI) $c h l-2^{-}$. The semi-selective medium was minimal medium supplemented with arginine, uracil and histidine.

$\begin{array}{lc}\text { Genotype } & \text { No. } \\ \text { arg ura chl- } & 119 \text { (parental) } \\ \text { arg ura chl+ } & 13 \\ \text { ura his chl+ } & 28 \\ \text { his } \text { chl }^{+} & 28\end{array}$

transferred to the sensitive cells, but only along with the chromosomal markers. The rate of transfer of $\mathrm{Ch}^{+}$was remarkably enhanced when the selection against the markers of the resistant parent (especially his $D_{3}$ ) was released (Table 2, last line, and Table 3 ), and it is therefore underestimated in conditions as in Table 2 (lines 2 to 4 ).

\section{The chl factor as a leading element in $\mathrm{Ch}^{+} \times \mathrm{Chl}^{-}$crosses}

In all the $\mathrm{Chl}^{+} \times \mathrm{Chl}^{-}$mixed cultures, the sensitive partner is overwhelmed by the resistant one, very likely because of the superior growth and sporulation of the latter. Due to the high frequency of recombinants observed (relative to the sensitive parent) spores from $\mathrm{SCPI}^{-} \mathrm{Chl}^{+} \times \mathrm{SCPI}^{-} \mathrm{Chl}^{-}$crosses were plated on a medium selective against only one marker of the resistant parent (semi-selective medium). There was a large variety of phenotypes among the resultant colonies. In cross $\mathrm{P}_{34}$, half the colonies were recombinant with respect to the chromosomal markers and all of these were resistant to chloramphenicol (Table 3). In a medium lacking histidine and phenylalanine, such as that selective for transferants (Table 2), the number of chromosomal recombinants detected would have been more than halved (44 instead of I02). In a similar experiment, involving the mixture of strains 3I2 $\mathrm{SCPI}^{-} \arg A I$ uraAI strAI chl ${ }^{+} \times 5$ II SCPI- metA2 pheAI strAI chl-7, plated on a medium selective against strain 3r2 (lacking arginine). Among 82 colonies 


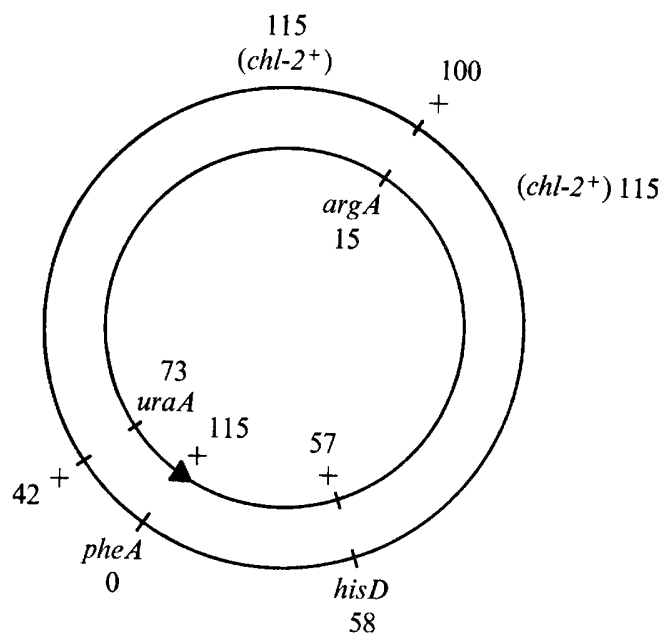

Fig. I. Frequency of alleles among recombinants from the mating: $3 \mathrm{I}^{6} \mathrm{SCPI}^{-}$his $\mathrm{D}_{3}$ pheAI strAI $c h l^{+}$(outer circle) $\times 506 \mathrm{SCPI}^{-} \arg A I$ uraAI strAI chl-2- (inner circle). The triangle indicates the allele selected for. Data are from Table 3. The frequency of $c h l-2^{+}$suggests a location to the right or left of $\arg A$.

tested 7I were resistant to chloramphenicol, and, of the latter, 6I were recombinant for the chromosomal markers.

The transfer of chromosomal markers was thus conditional upon the transfer of the $\mathrm{Chl}^{+}$trait. In fact the $\mathrm{Chl}^{+}$trait was also occasionally transferred alone. Thus when $\mathrm{ChI}^{+}$ and $\mathrm{Chl}^{-}$strains are mixed the $\mathrm{chl}$ factor appears to act as a leading element. From the number of markers transferred to the recombinant progeny it is evident that large regions of the $\mathrm{Chl}^{+}$parent chromosome are also involved in the transfer. The actual role of the chl element is open to several explanations.

\section{Attempts to localize the chl-2 factor by genetic analysis}

The recombinants obtained on the semi-selective medium (minimal medium supplemented with arginine, uracil and histidine) from cross $\mathrm{P}_{34}$ (strain $316 \mathrm{SCPI}^{-}$his $D_{3}$ phe AI strAI $\mathrm{chl}^{+} \times$strain $506 \mathrm{SCPI}^{-} \operatorname{argAI}$ uraAI strAI $\left.\mathrm{chl}_{-2^{-}}\right)$were analysed for the contribution of the unselected markers to the progeny (Table 3 ; Fig. I). From this analysis the $c h l$ factor appears to be linked to $\arg A I$ and the number of cross-overs required is minimized if it is located to the right of this marker. A location to the left of $\arg A$ requires quadruple crossovers to give the two arg ura his chl+ segregants (Table 3). No quadruple cross-over is required if the factor is located to right of $\arg A$.

\section{DISCUSSION}

A factor controlling resistance to chloramphenicol ( chl) was detected in $S$. coelicolor A3(2). It has been investigated in the absence of the SCPI plasmid (Vivian, I97I) to avoid interference by this fertility factor. The location of the $c h l$ factor is uncertain. Some lines of evidence indicate a chromosomal site to the right of the $\arg A$ locus. This conclusion is supported by consideration of the extreme selective advantage of the wild type $\mathrm{Chl}^{+}$state over the mutant $\mathrm{Chl}^{-}$, particularly in the late stages of colonial growth. In $\mathrm{Chl}^{+} \times \mathrm{Chl}^{-}$ 
crosses the $\mathrm{Chl}^{+}$recombinants, even if occasionally formed, would emerge at high frequency compared with the $\mathrm{Chl}^{-}$parent. Moreover, among the recombinants, those with the $\mathrm{Chl}^{+}$ phenotype would enjoy an absolute selective advantage thus explaining the lack of $\mathrm{Chl}^{-}$ recombinant phenotypes.

On the other hand, an extrachromosomal location of the chl factor is also suggested. The spontaneous appearance of the scarlet, chloramphenicol-sensitive phenotype, even if not readily quantified, is too frequent to be accounted for by gene mutation. Its rate of formation is, moreover, certainly underestimated by the frequency with which it is recovered, if one considers the extreme selective disadvantage of the variant during mycelial growth and sporulation. Repeated isolations are required to obtain a stable sensitive clone. This is indicative of a control by multiple elements, which are diluted out in the recloning process a situation not compatible with a trait controlled by a chromosomal gene. The recombination rate in $\mathrm{Chl}^{+} \times \mathrm{Chl}^{-}$crosses is increased up to several thousand-fold over that usual in $\mathrm{SCPI}^{-} \times \mathrm{SCPI}^{-}$matings, when referred to the $\mathrm{Chl}^{-}$parent. This is admittedly an overestimation because of the poor growth and sporulation of $\mathrm{Chl}^{-}$strains. However, the recombination rate relative to the $\mathrm{Chl}^{+}$parent is also increased, about Io-fold in one experiment $\left(\mathrm{P}_{3} \mathrm{I}\right)$ and I00-fold in another $\left(\mathrm{P}_{34}\right)$, even though the scarcity of the $\mathrm{Chl}^{-}$parent severely hinders expression of the fertility of the $\mathrm{Chl}^{+}$mate. Promotion of recombination by the $\mathrm{chl}$ factor, when it is carried by only one parent, is therefore very likely. Crosses of the type $\mathrm{Chl}^{-} \times \mathrm{Chl}^{-}$would be critical in testing this point. However, the residual instability of $\mathrm{Chl}^{-}$ strains and the difficulty of building up differently marked $\mathrm{SCPI}^{-}$strains with the same $\mathrm{Chl}$ phenotype have made these crosses not yet feasible. The role of chl as fertility factor is therefore still conjectural. If it promotes fertility, the chl factor would perform this function by associating with the chromosome at a site to the conventional right of the $\arg A$ locus, i.e. roughly opposite the site of attachment of the SCPr factor in NF strains. Its transfer would be bidirectional, as in the NF strains (Hopwood et al., 1973). A plasmid determining chloramphenicol production ( $c p p$ ) was recently reported in $S$. venezuelae (Akagawa, Okanishi \& Umezawa, 1975). Evidence for plasmid involvement was provided by the inability to locate cpp among standard chromosomal markers. Like $c h l$, $c p p$ was not transferred without recombination of chromosomal markers.

An enzyme inactivating chloramphenicol by acylation was reported by Argoudelis \& Coats (I97I) in a strain of $S$. coelicolor. However, this enzyme is not present in $S$. coelicolor A3(2) (Shaw \& Hopwood, I976) and hence cannot be responsible for the resistance to the drug of this latter strain. Other enzymes can be involved in resistance, for example one hydrolysing the amide bond in chloramphenicol was detected by Vining (I975) in Streptomyces 3022a, the chloramphenicol-producing species.

The nature of the chloramphenicol-resistance factor will hopefully be better understood when its behaviour has been investigated in further crosses involving the SCPI plasmid in various coupling arrangements with $\mathrm{chl}$.

We thank Mr A. Trippolini for technical assistance. This research was supported by the Italian National Research Council (C.N.R.) within project no. 7400270.

\section{REFERENCES}

Akagawa, H., Okanishi, M. \& Umezawa, H. (1975). A plasmid involved in chloramphenicol production in Streptomyces venezuelae : evidence from genetic mapping. Journal of General Microbiology 90, 336-346.

Argoudelis, A. D. \& CoATs, J. H. (I97I). Microbial transformation of antibiotics. VI. Acylation of chloramphenicol by Streptomyces coelicolor. Journal of Antibiotics 24, 206-208. 
Gregory, K. F. \& ShyU, W. J. (196I). Apparent cytoplasmic inheritance of tyrosinase competence in Streptomyces scabies. Nature, London 191, 465-467.

Hopwood, D. A. \& Sermonti, G. (1962). The genetics of Streptomyces coelicolor. Advances in Genetics II, 273-342.

Hopwood, D. A., Chater, K. F., Dowding, J. E. \& Vivian, A. (1973). Advances in Streptomyces coelicolor genetics. Bacteriological Reviews 37, 371-405.

KIRBY, R., WRIGHT, L. F. \& HopwOOD, D. A. (r975). Plasmid determined antibiotic synthesis and resistance in Streptomyces coelicolor. Nature, London 254, 265-267.

Puglia, A. M., Spada-Sermonti, I., Basile, S., Misuraca, F. \& Sermonti, G. (I973). Infectious transfer of a fertility factor in Streptomyces coelicolor. Genetical Research, Cambridge 21, 107-I 13.

Sermonti, G. (1975a). Plasmids in Streptomycetes. Microbial Genetics Bulletin 39, 10-1 r.

SERMONTI, G. (1975 b). Resistance factor in Streptomyces coelicolor A3(2). Microbial Genetics Bulletin 39, 5-6.

SHAw, W. V. \& Hopwood, D. A. (1976). Chloramphenicol acetylation in Streptomyces. Journal of General Microbiology 94, 159-166.

VINING, L. C. (I975). Methods in Enzymology 43, 734-737.

VIVIAN, A. (I97I). Genetic control of fertility in Streptomyces coelicolor A(3)2: plasmid involvement in the interconversion of UF and IF strains. Journal of General Microbiology 69, 353-364. 